\title{
Nutritional status of elderly assisted in primary care and their relationship with social determinants of health
}

\section{Estado nutricional de idosos assistidos na atenção básica e sua relação com determinantes sociais da saúde}

\author{
Georgia Ferreira da Silva BANDEIRA ${ }^{1}$ (D) 0000-0003-3480-937X \\ Rafael da Silveira MOREIRA ${ }^{1}$ iD 0000-0003-0079-2901 \\ Vanessa de Lima SILVA ${ }^{1}$ (D) 0000-0002-1562-1761
}

\section{A B S TR ACT}

\section{Objective}

To review the influence of social determinants of health in the nutritional status of the elderly assisted in a primary care Unit in a Recife, Pernambuco, Brazil, community.

\section{Methods}

This was a cross-sectional study with an analytical approach. The universe was composed of 129 elderly attending a family health unit in Recife, Pernambuco, Brazil. The data were collected according to a protocol. The effect of the association of independent variables with the body mass index was estimated using hierarchical logistic regression models, simple and multiple multinomial. The significance level was set at $5 \%$.

\section{Results}

There was a higher percentage of elderly people with excess weight (52.34\%) in the assessment of body mass index. On analysis of the Mini nutritional assessment, the risk of malnutrition was $38.76 \%$. On analysis of the calf circumference $13.39 \%$ of the elderly were malnourished. In the final model, the criteria for maintaining the elderly patients were the following: excess weight, marital status, hypertension, osteoarthritis and sewer

\footnotetext{
1 Universidade Federal de Pernambuco, Centro de Ciências da Saúde, Programa de Pós-graduação em Gerontologia. Endereço: s/n., Cidade Universitária, 50670-420, Recife, PE, Brasil. Correspondence to: VL SILVA. E-mail: <vanelima@gmail.com>.

Article based on the dissertation by GFS BANDEIRA, entitled "Influência de determinantes sociais no estado nutricional de idosos assistidos na atenção básica em uma comunidade do Recife”. Universidade Federal de Pernambuco; 2017.

How to cite this article

Bandeira GFS, Moreira RS, Silva VL. Nutritional status of elderly assisted in primary care and their relationship with social determinants of health. Rev Nutr. 2019;32:e190042 http://dx.doi.org/10.1590/1678-9865201932e190042
} 
destination. Elderly widowers had a higher chance $(O R=5.17)$ of having excess weight and not to have sewage network serving their home and be hypertense $(\mathrm{OR}=2.71$ e 2.83). The fact that the elderly have osteoarthritis also indicated a greater chance $(\mathrm{OR}=3.76)$ that they present excess weight.

\section{Conclusion}

Among the social determinants of health, the nutritional status of the elderly was associated with marital status, high blood pressure, osteoarthritis and basic sanitation. The social setting of the elderly is associated with their nutritional status.

Keywords: Elderly. Nutritional status. Social determinants of health.

\section{RE S U M O}

\section{Objetivo}

Analisar a influência de determinantes sociais da saúde no estado nutricional de idosos assistidos na atenção básica em uma comunidade do Recife, Pernambuco, Brasil.

\section{Métodos}

Trata-se de um estudo de corte transversal com abordagem analítica. O universo foi composto por 129 idosos usuários de uma Unidade de Saúde da Família localizada no Recife, Pernambuco, Brasil. Os dados foram coletados através de protocolos. O efeito da associação das variáveis independentes com o Índice de Massa Corporal foi estimado através de modelos hierarquizados de regressão logística multinomial simples e múltipla. O nível de significância foi fixado em 5\%.

\section{Resultados}

Houve maior percentual de idosos com excesso de peso (52,34\%) na avaliação do Índice de Massa Corporal. Na análise da Mini Avaliação Nutricional, o risco de desnutrição foi de 38,76\%. Na análise da circunferência da panturrilha, 13,39\% dos idosos eram desnutridos. Estado civil, hipertensão arterial, artrose e destino do esgoto permaneceram no modelo final, associados com o excesso de peso. Idosos viúvos tiveram maior chance $(O R=5,17)$ de ter excesso de peso, assim como os fatores relativos a possuir rede de esgoto e ter hipertensão arterial $(O R=2,71$ e 2,83). O fato de o idoso possuir artrose também apresentou maior propensão $(O R=3,76)$ ao excesso de peso.

\section{Conclusão}

Dentre os determinantes sociais da saúde, o estado nutricional do idoso foi associado ao estado civil, à hipertensão arterial, à artrose e ao saneamento básico. O contexto social do idoso está relacionado ao seu estado nutricional.

Palavras-chave: Idoso. Estado nutricional. Determinantes sociais da saúde.

\section{NTRO D U C T I O N}

In health, the epidemiological transition poses major challenges, especially the "epidemic of chronic diseases and disabilities" [1]. The complexity in identifying the factors that contribute to the diagnosis of the elderly is due to physiological and pathological changes, as well as social, economic and lifestyle conditions [2]. Among the functional changes in the elderly, the following stand out: changes in taste and chewing function [3], reduction in lean mass and increase in adipose tissue [4].

Social inequalities are transferred to the health field, becoming visible in the unequal health conditions of different groups, in the levels of health risks and in the differentiated access to resources available in the health system $[5,6]$.

Since nutritional status (overweight) is associated with a higher risk of chronic disease and is also influenced by physiological changes and social problems, it is of utmost importance to identify further evidence on the relationship between nutritional status and the Social Determinants of Health 
$(\mathrm{SDH})$ in order to contribute towards the definition of strategies to guide the prevention of diseases caused by nutritional disorders and, in addition, to direct the organization of programs for the elderly care. Social Determinants of Health refers to socioeconomic, cultural, environmental, social networks, lifestyle and individual characteristics.

Given the above, the aim of the study is to review the nutritional status of elderly people assisted in primary care and its association with social determinants of health.

\section{METHODS}

This is a cross-sectional design investigation with analytical approach, performed in a Family Health Unit in the city of Recife (PE), Brazil. The study participants were 60 years of age or older, had preserved cognition and ambulation. Bedridden elderly and amputees did not participate due to nutritional assessment.

The Family Health Unit had a universe of 165 registered elderly. Out of this total, 10 seniors refused to participate and 26 were not at home after two interview attempts. In view of the above, data were obtained from a total of 129 elderly.

For the identification of the SDH we used a protocol created for the investigation, containing a model of social determination of health [7]. A pilot study was conducted with the participation of 10 randomly selected individuals.

The information contained in the protocol included data on gender, age, marital status, reported morbidity, income, sewage destination, working time, community participation, lifestyle, weight, height, Calf Circumference (CC) and Mini Nutritional Assessment (MNA). Body Mass Index (BMI), CC and a reduced MNA version to assess nutritional status were used.

The BMI was calculated by the ratio of weight $(\mathrm{kg})$ and squared height $\left(\mathrm{m}^{2}\right)$. The cutoff points used were those established by Lipschitz [8]. The weight (in $\mathrm{kg}$ ) was measured using a Camry Model EB9013 Scale, with a maximum 150kg capacity. Height (in cm) was measured with the aid of a portable Nutri-Vida model stadiometer.

The BMI was used to review the association between social determinants of health and the nutritional status of the elderly. The CC was measured in the largest volume of the flexed leg at $90^{\circ}$ [9]. A circumference of $31 \mathrm{~cm}$ or more was considered adequate for men and women [10].

The reduced version of MNA includes information on food intake, weight loss, mobility, disease, neuropsychological problems and BMI. The score was classified into three categories [11].

After protocol validation in the pilot study, the MNA was applied to the rest of the population. The effect of the association of independent variables with BMI was estimated using hierarchical models of simple and multiple multinomial logistic regression, aiming at the odds ratio as the effect measure (Odds Ratio [OR]). The reference category was the eutrophic typology.

Within each hierarchical block, variables with $p<0.25$ were tested in multiple models. At the end, the variables that were statistically significantly associated $(p<0.05)$ remained in the final model. All tests were aided by the IBM ${ }^{\circledR}$ SPSS ${ }^{\circledR} 20$ Program (New York, United States).

This investigation is part of a larger study entitled "Social determinants of independence in the elderly: a look at the health of human communication" and is in accordance with resolution 466/12. It was approved by the Human Research Ethics Committee with opinion number 1,172,962 and CAAE 45957815.0.0000.5208. 


\section{R E S U L T S}

The study population consisted of 129 elderly, 28.9\% male and $71.1 \%$ female. Systemic Arterial Hypertension (SAH) was the most prevalent disease (Table 1). In addition, the main source of income for a high percentage of the elderly was retirement, social benefit and pension.

Table 1. Analysis of the simple multinomial logistic regression model according to individual characteristics. Recife (PE), 2018.

\begin{tabular}{|c|c|c|c|c|c|c|c|c|}
\hline \multirow{3}{*}{ Variables } & \multirow[b]{3}{*}{$n$} & \multirow[b]{3}{*}{ (\% total) } & \multicolumn{6}{|c|}{ BMI } \\
\hline & & & \multicolumn{3}{|c|}{ Low weight } & \multicolumn{3}{|c|}{ Overweight } \\
\hline & & & $O R^{a}$ & $95 \% \mathrm{Cl}^{\mathbf{b}}$ & $p$ value ${ }^{c}$ & $\mathrm{OR}^{\mathrm{a}}$ & $95 \% \mathrm{Cl}^{\mathbf{b}}$ & $p$ value $^{c}$ \\
\hline \multicolumn{9}{|l|}{ Age } \\
\hline Below the median (67) & 66 & $(51.6)$ & 0.61 & $0.18-1.99$ & 0.41 & 1.06 & $0.50-2.25$ & 0.87 \\
\hline Above the median $(67)^{*}$ & 62 & $(48.4)$ & 1.00 & - & - & 1.00 & - & - \\
\hline \multicolumn{9}{|l|}{ Gender } \\
\hline Female & 91 & $(71.1)$ & 0.67 & $0.21-2.18$ & 0.50 & 2.43 & $1.04-5.71$ & 0.04 \\
\hline Male* & 37 & $(28.9)$ & 1.00 & - & - & 1.00 & - & - \\
\hline \multicolumn{9}{|l|}{ Marital status } \\
\hline Single & 20 & $(15.6)$ & 1.20 & $0.23-6.06$ & 0.82 & 0.93 & $0.28-3.02$ & 0.90 \\
\hline Separated and divorced & 24 & $(18.7)$ & 1.00 & $0.16-6.25$ & 1.00 & 2.33 & $0.77-6.98$ & 0.13 \\
\hline Widower & 44 & (34.4) & 2.50 & $0.56-11.05$ & 0.22 & 5.16 & $1.85-14.41$ & $<0.01$ \\
\hline Married* & 40 & (31.3) & 1.00 & - & - & 1.00 & - & - \\
\hline \multicolumn{9}{|l|}{ Race / color } \\
\hline White & 26 & $(20.3)$ & 0.49 & $0.09-2.51$ & 0.39 & 0.76 & $0.30-1.90$ & 0.56 \\
\hline Nonwhite race* & 102 & $(79.7)$ & 1.00 & - & - & 1.00 & - & - \\
\hline \multicolumn{9}{|l|}{ Diabetes Mellitus } \\
\hline Yes & 34 & $(26.6)$ & 0.83 & $0.22-3.06$ & 0.78 & 0.71 & $0.30-1.66$ & 0.43 \\
\hline $\mathrm{No}^{*}$ & 94 & $(73.4)$ & 1.00 & - & - & 1.00 & - & - \\
\hline \multicolumn{9}{|c|}{ Systemic Arterial Hypertension } \\
\hline Yes & 93 & $(72.7)$ & 0.73 & $0.22-2.37$ & 0.60 & 3.66 & $1.49-8.97$ & $<0.01$ \\
\hline $\mathrm{No}^{*}$ & 35 & $(27.3)$ & 1.00 & - & - & 1.00 & - & - \\
\hline \multicolumn{9}{|l|}{ Arthrosis } \\
\hline Yes & 30 & $(23.4)$ & 1.02 & $0.18-5.71$ & 0.97 & 3.25 & $1.20-8.84$ & 0.02 \\
\hline $\mathrm{No}^{*}$ & 98 & (76.6) & 1.00 & - & - & 1.00 & - & - \\
\hline \multicolumn{9}{|l|}{ Arboviruses } \\
\hline Yes & 48 & $(37.5)$ & 0.56 & $0.15-2.05$ & 0.38 & 0.98 & $0.45-2.12$ & 0.97 \\
\hline $\mathrm{No}^{*}$ & 80 & $(62.5)$ & 1.00 & - & - & 1.00 & - & - \\
\hline
\end{tabular}

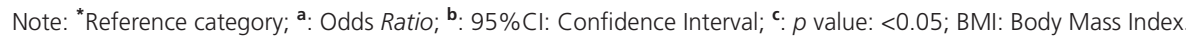

According to the evaluated nutritional parameters the average BMI found was $27.7 \mathrm{~kg} / \mathrm{m}^{2}$ (4.9 standard deviation). The mean value found for MNA and CC was 11.7 (2.2 standard deviation) and 34.4 (4.0 standard deviation) respectively. BMI detected a higher percentage of obese individuals, contrary to the MNA and CC indicators that showed a higher percentage of elderly people with adequate nutritional status. 
The variables associated with overweight in the simple model were: male gender, widowed marital status, SAH, arthrosis, absence of sewerage and lack of physical activity. Not having a sewerage system was more likely to be associated $(\mathrm{OR}=2.40)$ with overweight (Table 2$)$. There was a significant association between overweight and physical activity (Table 3). Although pathologies are not considered to be SDH, they were included as variables considering that they interfere with the individual's lifestyle.

The following variables remained significantly associated with overweight in the final model: widowed marital status, hypertension, arthrosis and absence of sewerage. Elderly widowers were more likely $(\mathrm{OR}=5.17)$ to be overweight (Table 4). None of the variables studied was associated with malnutrition in the models tested.

\section{DISCUSSION}

The nutritional status of the study population was mostly classified as overweight, considering the BMI. This result corroborates the results of research conducted in primary care $[12,13]$. In this connection, the increased prevalence of overweight and obesity in the Brazilian population and the decline in malnutrition in recent decades are indicative of an epidemic behavior of the problem [14].

Thus, an antagonism of temporal trends between malnutrition and obesity is established, defining one of the striking features of the country's nutritional transition process [14]. Obesity is associated with a high incidence of cardiovascular disease, cancer and diabetes, thus influencing the morbidity and mortality profile of populations [15].

Table 2. Analysis of the simple multinomial logistic regression model according to socioeconomic, living and working conditions, Recife (PE), 2018.

\begin{tabular}{|c|c|c|c|c|c|c|c|c|}
\hline \multirow{3}{*}{ Variables } & \multirow[b]{3}{*}{$\mathrm{n}$} & \multirow[b]{3}{*}{ (\% total) } & \multicolumn{6}{|c|}{ BMI } \\
\hline & & & \multicolumn{3}{|c|}{ Low weight } & \multicolumn{3}{|c|}{ Overweight } \\
\hline & & & $\mathrm{OR}^{\mathrm{a}}$ & $95 \% \mathrm{Cl}^{\mathbf{b}}$ & $p$ value $^{c}$ & $\mathrm{OR}^{\mathrm{a}}$ & $195 \% \mathrm{Cl}^{\mathbf{b}}$ & $p$ value $^{c}$ \\
\hline \multicolumn{9}{|c|}{$\begin{array}{l}\text { General socioeconomic and environmental } \\
\text { conditions }\end{array}$} \\
\hline Source of income & - & - & - & - & - & - & - & - \\
\hline Informal work & 13 & $(10.2)$ & 1.50 & $0.15-14.4$ & 0.72 & 1.00 & $0.16-5.98$ & 1.00 \\
\hline Retirement/Social benefit/Pension & 103 & $(80.5)$ & 0.52 & $0.08-3.29$ & 0.49 & 0.96 & $0.25-3.65$ & 0.95 \\
\hline Third parties* & 12 & $(9.3)$ & 1.00 & - & - & 1.00 & - & - \\
\hline \multicolumn{9}{|l|}{ Family income } \\
\hline 0 to 1 minimum wage & 96 & $(75.8)$ & 1.41 & $0.33-5.87$ & 0.63 & 1.03 & $0.44-2.44$ & 0.93 \\
\hline 1.1 to 3 minimum wage* & 31 & $(24.2)$ & 1.00 & - & - & 1.00 & - & - \\
\hline Life and work conditions & - & - & - & - & - & - & - & - \\
\hline Sewer Destination & - & - & - & - & - & - & - & - \\
\hline Pit. ditch and others & 59 & $(46.1)$ & 2.36 & $0.72-7.74$ & 0.15 & 2.40 & $1.09-5.24$ & 0.02 \\
\hline Sewerage system* & 69 & (53.9) & 1.00 & - & - & 1.00 & - & - \\
\hline Working time & - & - & - & - & - & - & - & - \\
\hline Below the median ( 30 years of age) & 67 & $(58.3)$ & 1.22 & $0.34-4.32$ & 0.74 & 1.96 & $0.86-4.42$ & 0.10 \\
\hline Above the median (30 years of age) ${ }^{*}$ & 48 & $(41.7)$ & 1.00 & - & - & 1.00 & - & - \\
\hline
\end{tabular}

Note: "Reference category; ${ }^{\text {a. }}$ Odds Ratio; b. $95 \% \mathrm{Cl}$ : Confidence Interval; c. $p$ value: <0.05; BMI: Body Mass Index. 
Table 3. Analysis of the simple multinomial logistic regression model according to social and community networks and lifestyle of individuals. Recife (PE), 2018

\begin{tabular}{|c|c|c|c|c|c|c|c|c|}
\hline \multirow{3}{*}{ Variables } & \multirow[b]{3}{*}{$\mathrm{n}$} & \multirow[b]{3}{*}{ (\% total) } & \multicolumn{6}{|c|}{$\mathrm{BMI}$} \\
\hline & & & \multicolumn{3}{|c|}{ Low weight } & \multicolumn{3}{|c|}{ Overweight } \\
\hline & & & $\mathrm{OR}^{\mathrm{a}}$ & $95 \% \mathrm{Cl}^{\mathbf{b}}$ & $p$ value $^{c}$ & $O R^{a}$ & $95 \% \mathrm{Cl}^{\mathbf{b}}$ & $p$ value \\
\hline \multicolumn{9}{|c|}{ Social and community networks } \\
\hline \multicolumn{9}{|c|}{$\begin{array}{l}\text { Participation of socialization group } \\
\text { activity }\end{array}$} \\
\hline Yes & 38 & $(29.7)$ & 0.49 & $0.09-2.51$ & 0.39 & 1.89 & $0.81-4.38$ & 0.13 \\
\hline $\mathrm{No}^{*}$ & 90 & $(70.3)$ & 1.00 & - & - & 1.00 & - & - \\
\hline \multicolumn{9}{|l|}{ Individuals life style } \\
\hline \multicolumn{9}{|l|}{ Physical activity } \\
\hline Yes & 24 & $(18.8)$ & 0.58 & $0.06-5.45$ & 0.63 & 3.01 & $1.02-8.81$ & 0.04 \\
\hline $\mathrm{No}^{*}$ & 104 & $(81.2)$ & 1.00 & - & - & 1.00 & - & - \\
\hline \multicolumn{9}{|c|}{ Perception of nutritional health } \\
\hline Excellent and good & 71 & $(55.5)$ & 3.38 & $0.37-30.39$ & 0.27 & 0.65 & $0.24-1.76$ & 0.40 \\
\hline Regular & 32 & $(25.0)$ & 2.00 & $0.17-22.79$ & 0.57 & 0.70 & $0.23-2.18$ & 0.54 \\
\hline Bad and very bad* & 25 & (19.5) & 1.00 & - & - & 1.00 & - & - \\
\hline \multicolumn{9}{|l|}{ Stress } \\
\hline Yes & 50 & (39.1) & 0.35 & $0.08-1.43$ & 0.14 & 1.02 & $0.47-2.18$ & 0.95 \\
\hline $\mathrm{No}^{*}$ & 78 & $(60.9)$ & 1.00 & - & - & 1.00 & - & - \\
\hline
\end{tabular}

Note: "Reference category; a: Odds Ratio; b. 95\%Cl: Confidence Interval; c: $p$ value: <0.05; BMI: Body Mass Index.

Table 4. Analysis of the multiple hierarchical model of multinomial logistic regression, Recife (PE), 2018.

\begin{tabular}{|c|c|c|c|c|c|c|c|c|}
\hline \multirow{3}{*}{ Variables } & \multirow[b]{3}{*}{$\mathrm{n}$} & \multirow[b]{3}{*}{ (\% total) } & \multicolumn{6}{|c|}{ BMI } \\
\hline & & & \multicolumn{3}{|c|}{ Low weight } & \multicolumn{3}{|c|}{ Overweight } \\
\hline & & & $O R^{a}$ & $95 \% \mathrm{Cl}^{\mathbf{b}}$ & $p$ value $^{c}$ & $\mathrm{OR}^{\mathrm{a}}$ & $95 \% \mathrm{Cl}^{\mathbf{b}}$ & $p$ value \\
\hline \multicolumn{9}{|l|}{ Individual characteristics } \\
\hline \multicolumn{9}{|l|}{ Marital status } \\
\hline Single & 20 & $(15.6)$ & 1.15 & $0.22-5.99$ & 0.86 & 0.76 & $0.21-2.75$ & 0.67 \\
\hline Separated and divorced & 24 & $(18.8)$ & 0.83 & $0.12-5.52$ & 0.85 & 1.95 & $0.59-6.39$ & 0.26 \\
\hline Widower & 44 & (34.3) & 2.64 & $0.57-12.24$ & 0.21 & 3.96 & $1.31-11.89$ & 0.01 \\
\hline Married* $^{*}$ & 40 & (31.3) & 1.00 & - & - & 1.00 & - & - \\
\hline \multicolumn{9}{|l|}{ Referred morbidity } \\
\hline \multicolumn{9}{|c|}{ Systemic Arterial Hypertension } \\
\hline Yes & 93 & $(72.7)$ & 0.69 & $0.20-2.39$ & 0.56 & 3.27 & $1.21-8.83$ & 0.01 \\
\hline $\mathrm{No}^{*}$ & 35 & $(27.3)$ & 1.00 & - & - & 1.00 & - & - \\
\hline \multicolumn{9}{|l|}{ Arthrosis } \\
\hline Yes & 30 & $(23.4)$ & 0.98 & $0.17-5.75$ & 0.99 & 3.73 & $1.22-11.38$ & 0.02 \\
\hline $\mathrm{No}^{*}$ & 98 & $(76.6)$ & 1.00 & - & - & 1.00 & - & - \\
\hline \multicolumn{9}{|l|}{ Live and work conditions } \\
\hline \multicolumn{9}{|l|}{ Sewer Destination } \\
\hline Pit. ditch and others & 59 & $(46.1)$ & 2.36 & $0.69-8.00$ & 0.16 & 2.71 & $1.12-6.55$ & 0.02 \\
\hline Sewerage system* & 69 & $(53.9)$ & 1.00 & - & - & 1.00 & - & - \\
\hline
\end{tabular}

Note: *Reference category; ${ }^{\text {: }: ~ O d d s ~ R a t i o ; ~ b: ~} 95 \% \mathrm{Cl}$ : Confidence Interval; c: $p$ value: <0.05; BMI: Body Mass Index. 
Opposite results were observed regarding MNA, which found a higher percentage of elderly people with adequate nutritional status. However, in the study by Koren-Hakim et al. [16], these results differ. There was an excess of elderly people classified as nutritional risk and malnourished, which may be due to the sample studied $(n=215)$ and the hospital environment of the study. In a recent study by Oehlschlaeger et al. [17], a higher distribution of elderly people with adequate nutritional status for MNA and overweight was also found when classified according to the BMI.

In the present study, none of the variables studied was associated with malnutrition in the tested models. In addition to the MNA tool being directed to malnourished patients, the excess of obese individuals due to the nutritional transition may have influenced the reduced number of malnourished elderly. In turn, it did not identify significant association.

Within the context of SDH, economic, cultural and environmental conditions are prevalent in society. Income and labor market conditions in the country influence the other layers of the SDH model. Purchasing power, the income of a given society, for example, can influence an individual's choice regarding housing, work, social interactions, and eating habits [18].

The health-disease balance is determined by a multitude of factors of social, economic, cultural, environmental and biological origin. Despite the unquestionable influence of factors external to the individual, these factors have not always been included in policy making [19].

From the significant relationship between overweight and widowed elderly it can be inferred that the condition of living alone is often associated with lack of company during meals, implying a higher consumption of low nutritional quality food and fast food that is hypercaloric and high in sodium, favoring the onset of SAH.

Similar data relating excess weight and living conditions were only shown in the study by Pereira et al. [13]. Loneliness and lack of personal networks were associated with mortality risk [20].

Older people living alone would be more vulnerable to nutritional disorders (deficit or excess) [13]. Overweight, in addition to being an independent risk factor for Cardiovascular Disease (CVD), is a predisposing factor for $\mathrm{SAH}$. It has been shown in other investigations that overweight is associated to the risk of hypertension and other CVDs [21]. The results of this investigation support the data found by Neumann et al. [22] regarding the association of hypertension and overweight.

Overweight in the elderly was also associated with arthrosis, confirming the higher risk of developing these diseases among the obese, often due to excess weight, especially on the knee and hip. Such relationship points to the establishment of greater dependence on activities of daily living, in addition to greater frailty of the elderly [13].

Unfavorable living conditions, such as housing without sewerage, were related to overweight elderly. Unfavorable financial conditions affect the nutritional status, considering the purchasing of inferior foodstuffs. Excessive consumption of foods with low nutritional value can lead to overweight and other disorders. According to Canêdo [23], elderly people enjoying high levels of education and income, low morbidity and adequate weight are associated with successful aging. The homogeneity of the population and the universe studied are considered limitations of the present study. The small number of individuals analyzed $(n=129)$ may have been a limiting factor for some analyses. Among all the factors reviewed, a relationship between nutritional status and four of the variables studied (widowed marital status, SAH, arthrosis and absence of sewerage system) was found. 


\section{CONCLUSION}

The association between overweight and lack of basic sanitation, the presence of arthrosis, hypertension and widowed marital status reiterates the need to study the nutritional conditions of the elderly population from the perspective of social determinants, so that adjustments in public prevention and health promotion policies be suggested, based on the understanding that these factors contribute with the nutritional problems.

\section{ACKNOWLEDGMENTS}

I am grateful to my colleagues Angelina, Emília and Patrícia who made this investigation possible, contributing strenuously to the data collection.

\section{CONTRIBUTORS}

GFS Bandeira, investigation design, literature survey, data collection and analysis, article writing, article submission and procedures. RS Moreira, co-guidance, investigation design, data analysis, article writing. VL Silva, guidance, investigation design, data analysis, preparation and proof reading of the article writing, approval of the final version.

\section{REFERENCES}

1. Miranda GMD, Mendes ACG, Silva ALA. O envelhecimento populacional brasileiro: desafios e consequências sociais atuais e futuras. Rev Bras Geriatr Gerontol. 2016;19(3):507-19. http://dx.doi.org/10.1590/1809-9 8232016019.150140

2. Ferreira AA, Menezes MFG, Tavares EL, Nunes NC, Souza FP, Albuquerque NAF, et al. Estado nutricional e autopercepção da imagem corporal de idosas de uma Universidade Aberta da Terceira Idade. Rev Bras Geriatr Gerontol. 2014;17(2):289-301.

3. Neumann L, Schauren BC, Adami FS. Sensibilidade gustativa de adultos e idosos. Rev Bras Geriatr Gerontol. 2016;19(5):797-808. http://dx.doi.org/10.1590/1809-98232016019.150218

4. Pisciottano MVC, Pinto SS, Szejnfeld VL, Castro CHM. The relationship between lean mass, muscle strength and physical ability in independent healthy elderly women from the community. J Nutr Health Aging. 2014;18(5):554-8. http://dx.doi.org/10.1007/s12603-013-0414-z

5. Marmot M. The health gap: The challenges of an unequal world. London: Blomsbury; 2015.

6. Deaton, A. The great escape: Health, wealth, and the origins of inequality. Princeton: Princeton University Press; 2015.

7. Dahlgren G, Whitehead M. Policies and strategies to promote social equity in health. Estocolmo: Institute for Future Studies; 1991.

8. Lipschitz DA. Screening for nutritional status in the elderly. Primary Care. 1994;21(1):55-67.

9. Moraes EM, Lanna FM. Avaliação multidimensional do idoso. Belo Horizonte: Folium; 2014.

10. Moraes EN, Pereira AMVB, Azevedo RS, Moraes FL. Avaliação multidimensional do idoso. Curitiba: Secretaria do Estado de Saúde; 2018 [citado 11 mar 2019]. Disponível em: http://www.saude.pr.gov.br/arquivos/File/ AvaliacaoMultiddoldoso_2018_atualiz.pdf

11. Mussoi TD. Avaliação nutricional na prática clínica: da gestação ao envelhecimento. Rio de Janeiro: Guanabara Koogan; 2014.

12. Silveira EA, Vieira LL, Jardim TV, Souza JD. Obesidade em idosos e sua associação com consumo alimentar, diabetes Mellitus e infarto agudo do miocárdio. Arq Bras Cardio. 2016;107(6):509-17. 
13. Pereira IFS, Spyrides MHC, Andrade LMB. Estado nutricional de idosos no Brasil: uma abordagem multinível. Cad Saúde Pública. 2016;32(5):178-189.

14. Batista Filho M, Rissin A. A transição nutricional no Brasil: tendências regionais e temporais. Cad Saúde Pública. 2003;19(Supl. 1):181-91. http://dx.doi.org/10.1590/S0102-311X2003000700019

15. Tomasi E, Nunes BP, Thumé E, Silveira DS, Siqueira FV, Piccini RX, et al. Utilização de serviços de saúde no Brasil: associação com indicadores de excesso de peso e gordura abdominal. Cad Saúde Pública. 2014;30(7):1515-24.

16. Koren-Hakim T, Weiss A, Hershkovitz A, Otzrateni I, Anbar R, Gross Nevo RF, et al. Comparing the adequacy of the MNA-SF, NRS-2002 and must nutritional tools in assessing malnutrition in hip fracture operated elderly patients. Clinical Nutrition. 2016 [cited 2017 Jan 10];35:1053-8. Available from: https://www.ncbi.nlm.nih. gov/pubmed/26231340

17. Oehlschlaeger MHK, Pastore CA, Cavalli AS, Gonzalez MC. Nutritional status, muscle mass and strength of elderly in Southern Brazil. Nutr Hosp. 2015;31(1):363-70.

18. Organização Mundial da Saúde. Rumo a um modelo conceitual para análise e ação sobre os determinantes sociais de saúde: Comissão de Determinantes Sociais de Saúde. Brasília: OMS; 2005.

19. Carrapato P, Correia P, Garcia B. Determinante da saúde no Brasil: a procura da equidade na saúde. Saúde Soc. 2017;26(3):676-89. http://dx.doi.org/10.1590/S0104-12902017170304

20. Ellwardt L, Van Tilburg T, Aartsen M, Wittek R, Steverink N. Personal networks and mortality risk in older adults: A twenty-year longitudinal study. Plos One. 2015;10(3):1-14.

21. Soar C. Prevalência de fatores de risco cardiovascular em idosos não Institucionalizados. Rev Bras Geriatr Gerontol. 2015;18(2):385-95.

22. Neumann B, Conde SR, Lemos JRN, Moreira TR. Associação entre o estado nutricional e a prevalência de doenças crônicas não transmissíveis em idosos residentes no município de Roca Sales-RS. Rev Bras Ciênc. Envelhecimento Hum. 2014;11(2):166-77.

23. Canêdo AC, Lopes CS, Lourenço RA. Prevalence of and factors associated with successful aging in Brazilian older adults: Frailty in Brazilian older people Study (FIBRA RJ). Geriatr Gerontol Int. 2018;18:1280-5. http:// dx.doi.org/10.1111/ggi.13334 